\title{
Architecture typology of a British-era colonial schools at the World Heritage Sites of Georgetown and Melaka: Impact on heritage building conservation sector
}

\author{
Muhammad Adam Che Yusof ${ }^{1 *}$, and $A$ Ghafar Ahmad ${ }^{2}$ \\ ${ }^{1,2}$ School of Housing, Building and Planning, Universiti Sains Malaysia
}

\begin{abstract}
Colonial schools are among the most valuable and precious treasures from the British administration era. The architectural characteristics of the schools contain a wealth of meaning and philosophy in each of the building details that is not found in modern schools nowadays. However, in this era of rapid development, the status of colonial schools is unclear in terms of their heritage status and significance towards society or even the authorities. Moreover, some colonial schools that are now overshadowed by new buildings that were built inside of the school compound and its surrounding. Besides, the local authorities themselves are lacking on the documentation of colonial schools in terms of their value, and the principles behind the architectural style of the colonial schools that could prove beneficial to many parties later as a reference. This article will outline the method to handle this issue besides suggesting a relationship between the value of the colonial architecture and its history at both heritage sites of Georgetown and Melaka. Besides that, we will also classify different colonial schools according to their architectural style. To ensure the objectives are achieved, qualitative methods will be applied including several approaches such as descriptive method, historical method and content analysis method. Hence, this research can serve as a reference point and documentation, especially for conservation purposes of colonial schools. In addition, the local authorities can also improve their Conservation Management Plan (CMP) by adding a colonial schools sector for conservation work and later guidelines. This research will hopefully also encourage the younger generation on the importance of skills and knowledge in the heritage building conservation sector.
\end{abstract}

Keywords: Building Conservation, Typology, Colonial School, Architecture Style

\section{Introduction}

Malaysia had been colonized by several powers such as the Portuguese, Dutch and British in the past. These colonisers had their own cycle of development and downfall during their administration in Malaya [1]. In the process, several developments were brought to the country in terms of economic, education, trading and politics. As we look into the development and architectural part, it is clear that the colonisers had better expertise than us at the time. The colonial buildings that had been built are the most valuable properties to the country and were adapted from each colonisers' own architectural style albeit modified to suit the climate and context of this country, which is hot and humid. As such, the buildings demonstrate the combination of several of culture influences such as Chinese and Indian as they immigrated to Malaya [2]. This is clearly shown in the uniqueness of architectural style of colonial buildings and its motifs that contains heritage value that should be preserved until today. The term colonial buildings usually refers to shop houses, places of worship and government offices which are more popular among society. However the schools that had been left over from the colonial era should also be recognised as historic buildings that need to be preserved to maintain and protect the historical and aesthetic values of the buildings. 


\section{Background of the study}

In the field of historical building conservation, there is a variety of approaches that can be appled. The understanding of each conservation work approach is very important to prevent any confusion during the conservation works being carried out [3]. Furthermore, it is important to ensure the originality, authenticity and art of the historical buildings is well preserved and not affected by any circumstances since the historical buildings differ from each other in terms of architectural style, structure, function and also types of defect so that the conservation works that need to be applied will also be different, based on the type of building [4]. This article will focus on the assessment of the different colonial school buildings based on their architectural style, building façade, building material, schools' site and also the arrangement and division of spaces in the buildings and their surroundings. In addition, this article will also attempt to link the history of the schools with the elements of architecture while highlighting methods to solve the issues and problem. The term "Typology" carries a broad meaning in categorizing certain object or figure physically to expose the values concealed behind the physical structure, not to mention its link with history. In Malaysia, research related to typology is rarely published especially if it is related to colonial schools in the World Heritage Sites. Most of the previous research on colonial buildings are more focused on shop houses in these historical cities. Hence, with the establishment of this kind of typology research it could indirectly contribute and impact on the building conservation sector in Malaysia; at the same it will hopefully provide a valuable resource to many other parties such as academicians, historians, school management or even the local authorities for various other uses in the future.

Table 1. Types of typology for this research paper.

\begin{tabular}{|l|l|}
\hline \multicolumn{1}{|c|}{ Typology } & \multicolumn{1}{c|}{ Explanation } \\
\hline Facade & $\begin{array}{l}\text { To study the design that have been used to produce a façade that resembles its own architectural } \\
\text { style during construction such as window design, door, wall ornament and column. [5,6] }\end{array}$ \\
\hline Material & $\begin{array}{l}\text { Identify the type of material used during the construction, such as the use of basic materials; brick, } \\
\text { building roof, paint. [6] }\end{array}$ \\
\hline Plan & $\begin{array}{l}\text { Understanding the interior layout plan of the building and also the actual location of the colonial } \\
\text { school; main road, back lane and the interior spaces. [5] }\end{array}$ \\
\hline
\end{tabular}

\section{Problem Statement}

To date, there are still many historical building in this country that are still facing defects whether to their façade, structure or else have been renovated without any proper conservation works. There are some buildings that have been abandoned by their owners and not well maintained due to lack of knowledge about conservation matters and also no initiative by the owners to preserve the buildings [ 7]. Based on observation, there are some old buildings that have lost their authenticity in their design, building material and architectural style due to the lack of proper maintenance and also the huge scale of renovation conducted on the building [8]. The weaknesses in maintaining such heritage treasure had caused serious defects to the structure and also the building fabric. Furthermore, based on a study by Raja Nafida Raja Shahminan (2008) there are some of the interior layout of shop houses in Melaka that had been changed by the building owner without any guidelines. In the case of this article, the researchers have selected the typology for the colonial school, and clearly there are many colonial schools nationwide, including those found in George Town and Melaka. These schools were used since inception until now without any change of use. Colonial schools have tourism potential and could attract academician to study more about the school's history, its architectural design or maybe as reference in developing new schools provided these colonial schools are well maintained and preserved with proper conservation methods.

\subsection{Lack of documentation from local authorities.}

In the Special Area Plan (SAP) of George Town and Melaka, there is a lack of specific and detailed information about colonial buildings or precisely the colonial schools in both heritage cities. Based on the researchers' observation, authorities such as Heritage Conservation Department, Pulau Pinang City Council (MBPP) and Building Control Department, Melaka Historical City Department (MBMB) agreed that for now they are lacking in terms of detailed documentation regarding the colonial school either from the aspect of pattern or architectural design, structure and the building materials or even the influencing of the interior layout pattern and the colonial schools' façade. 


\subsection{Neglected heritage status of colonial school.}

According to the online news portal Mstar.com.my on October 2016, Penang Free School once planned to change the name of the school to Sekolah Menengah Kebangsaan Penang Free School. However, Raja of Perlis, Tuanku Syed Sirajuddin Syed Putra Jamalullail who is also one of its distinguished alumni insisted to maintain the original name of the school as the school is renowned as the oldest English Stream School in Malaysia and South East Asia. Besides this, there are also other cases involving schools in Seremban namely SMK Convent that was demolished for a new water reservoir. Similarly, SJK(T) Convent Seremban was also demolished and new school buildings were rebuilt. This shows that the sentimental values of the old school are ignored in the eyes of some of our community who fail to make the effort to preserve and take care of these colonial schools.

\subsection{Low quality of the school building.}

The façade quality of the colonial schools nowadays are declining as the buildings are aging year by year. In this case, the schools management and local authorities have to ensure that any related issues connected with the buildings should not be overlooked so that in the future it will not harm the building further. Moreover, the schools management should not change the façade or any part of the building by themselves without adhering to appropriate guidelines and permission from the local authorities. This is to ensure that all renovation works that are planned are based on the prepared guidelines so that the conservation work will be in line with the conservation act.

\section{Research Area}

In Malaysia, there are several places and cities recognized by UNESCO as World Heritage Sites such a George Town and Melaka. The Asian and European influences in these heritage cities are clearly shown by their historical buildings such as the places of worship, government buildings, shop houses and fortresses. Both cities are recognized by UNESCO on $7^{\text {th }}$ July 2008 and had been chosen as researcher's scope of study area [9].

\subsection{George Town, Pulau Pinang.}

George Town is one of the fastest and rapidly developing cities in Malaysia located 325 kilometres north from Kuala Lumpur. The city that was built at foothills was discovered by the English trader, Sir Francis Light in 1786 and at that time there was no development or artistic buildings because at first it was not intended to become a settlement [10]. Since the 1900s, many buildings were built such as the administration offices, housing, places of worship - mosques, churches, temples - and schools. Those buildings adopted the combination of local architecture with several of foreign influences such as English, Arab, China and India making them until today one of the examples of precious heritage architecture that needs to be protected. Furthermore, as George Town is one of the historical city in Malaysia, it is divided into two zones whereby the core zone consists of 109.38 hectares while the buffer zone encompasses 150.04 hectares [11].

\subsection{Melaka Historical City, Melaka.}

Melaka Historical City is the capital city for Melaka State located 125 kilometre south of Kuala Lumpur and was the $8^{\text {th }}$ city that existed in South Peninsular Malaysia. Located near the estuary of Melaka River that flows towards the Straits of Melaka, this city contains thousands of history making it well developed today beginning from the Melaka Sultanate Era until the colonization of Portuguese, Dutch and British [reference 9]. Consisting of two zones, Melaka covers 242.8 hectares of core zone which is $83.4 \%$ of the city and 45.3 hectares of buffer zone that consists of $15.7 \%$ of the city area.

Table 2. Colonial schools at both heritage cities.

\begin{tabular}{|l|l|l|l|}
\hline \multicolumn{1}{|c|}{ Melaka } & \multicolumn{1}{|c|}{ Age } & \multicolumn{1}{c|}{ George Town } & \multicolumn{1}{c|}{ Age } \\
\hline SMK \& SK St Francis & $1880(137$ years $)$ & St. Xavier Institution & 1852 (165 years) \\
\hline SK Banda Hilir & $1908(109$ years $)$ & $\begin{array}{l}\text { SMK \& SK Convent Light } \\
\text { Street }\end{array}$ & 1852 (165 years) \\
\hline SK Sacred Heart Convent & $1905(106$ years $)$ & & \\
\hline SMK Tinggi Melaka & $1826(191$ years $)$ & & \\
\hline
\end{tabular}


Based on the table above, the schools are selected based on the criteria as follows:

i. Located in the area of UNESCO World Heritage Sites: core and buffer zone.

ii. Aged 100 years old and above.

iii. Implemented the colonial architecture style.

iv. Only heritage buildings in category I and II.

\section{Objectives}

The overall objective of this research is to know and identify the typology of the colonial schools' architecture style while drafting the method and approaches to address the related issues.

5.1 Drafting methods to address the issues and problems related to the maintenance of colonial school buildings at the George Town and Melaka World Heritage Sites.

This objective is to research and develop the method from several parties to overcome the related issues regarding the colonial schools buildings.

5.2 Classify each different colonial school according to the school's architectural style.

Classifying each different school according to their architectural design and principle that had been applied based on the given typology in this article.

5.3 Establishing the relationships between colonial architecture and school history at George Town and Melaka World Heritage Sites.

To identify the relationship between architectural design of the buildings and the history of the school.

\section{Methodology}

The research applies Qualitative method in this study with several approaches. The type of approaches in the data collection of this study are as follows:

6.1 Observation : Applying the structured observation means that researcher needs to identify the aspects required in the method such as the types, patterns or the style of the buildings. The observation method will be recorded through the prepared inventory form and also through pictures captured on the site.

6.2 Document Analysis: This approach is required to obtain additional data and resources other than interview and observation since it is the fastest way to collect more references. It is use to obtain the validity in the research that also can shaped the guidelines of the research. For example, historical approach entails document analysis method that can be used to seek the connection between the history and the condition of the building. Historical approaches will also lead to the related issues from the historical observation and determines from which angle the research could be done [5].

6.3 Interview : A technique of collecting data by interviewing the research subjects. In this research, semi-structured interviews are used which means the questions are already prepared by researcher but the arrangement and the sequence can be modified [12]. There may also be additional questions, or some of the prepared questions may even be skipped during the interview session.

6.4 Case Study: This approach helps researchers to select the suitable case study for the research based on the specific criteria that have been chosen to achieve the goals of the study. For instance, this study identified several criteria to select the best schools to be included, such as the schools must be within World Heritage Site boundary, built in colonial era and categorized as Category I and II Heritage Buildings. 


\section{Discussion}

For this study, the findings might be useful for many parties as a reference or record regarding the particular schools. Moreover, it also will benefit the construction sector such as the conservator, contractor and local authorities since there are prepared documentations containing the architectural elements of the school if there is any conservation work that needs to be worked out. The findings of this study will explain the typology of the selected schools based on their types of typology which can be seen from their façade, material and plan. It will also describe the architectural style and patterns of the schools which make it easier to categorize and differentiate between school's buildings. On the other hand, some limitations include failure to study some of the schools because the land owner refused to grant permission, and also the lack of the cooperation from several parties; local authorities, school's management and consultants, and the schools are restricted areas rendering them out of bounds without proper permission.

\section{Impact on Conservation Sector}

\subsection{Improvement on Conservation Management Plan (CMP)}

It will help the planning from local authorities in managing the heritage city from the aspect of conservation buildings especially in the context of colonial schools. In this case, this article could help to categorize the colonial school in their own specific category without needing to be categorized under one big group which is in category I and II buildings.

\subsection{References for several parties}

The typology of the schools are very important as they show the detailed elements that were hidden under the schools buildings. Academicians, historians and conservator can use this typology documentation as their references. On the other hand, schools management and the ministry for example could make this typology paperwork as a reference and archive document for future use.

\subsection{Enhancing the quality of conservation works.}

This is shown when the conservation works for those colonial school are running, so that the detail documentation about the schools are already prepared whether from the history aspect until its architectural concept. For instance, conservator and contractor that are planning to run the conservation works could refer the building material used by the schools for them to get the actual material from any related supplier based on the selected criteria without breaking the guidelines. It is also make the conservation works easier when the detailed documentation are already prepared especially when it comes to the building typology as it act as a measurement to the conservation works procedure.

\section{Conclusion}

As a conclusion, those colonial school building contains the different layout of space, design and also the material use from one another. Therefore, to run the conservation works on those buildings, the typology aspect need to be carried out and not only focusing on the preservation on the building facade. The typology aspect that need to be carry out are the facade, plan and material typology. Typology study not only can be done for colonial school building but it is also can be done to any historical building such as the Malay houses, museums, clock tower or even fotresses. In addition, Malaysia and local authorities already have their own guidelines and Akta Warisan Kebangsaan 2005 that are still in use, there are still some certain parts and section that need to be impove for the benefit of conservation works management. The earlier planning also important to determine the appropriate method to solve some issues so that the correct technique can be apply to the particular buildings and ensuring the authenticity is well preserved. In fact, with the existence of typology for those colonial schools may also reminds the early moments of the schools were built hence it will reinforces the historical elements in the school building. 


\section{References}

1. A. S. Hassan, S.R.C Yahaya, Architecture and Heritage Buildings in George Town Penang (2012)

2. http://zahirzainudin.blogspot.my/2014/06/kepelbagaian-seni-bina-dan-struktur.html

3. A. A. Hussin, Pemuliharaan dan pemeliharaan warisan di Malaysia.(2011)

4. A. G. Ahmad Rangka kerja pemuliharaan bangunan warisan di Malaysia. Bengkel Konservasi Monumen dan Tapak Tanah Bersejarah, 27-29hb. November 2006, Melaka. Kerajaan Negeri Melaka dengan kerjasama Perbadanan Muzium Melaka (PERZIM), Melaka.

5. R. N. R. Shaminan, Kajian Tipologi Rumah Kedai Awal Era Belanda di Bandar Melaka : Sumbangan Kepada Bidang Pemuliharaan di Malaysia (2008)

6. http://tutirahayu-knowledge.blogspot.my/2012/05/tipologi-arsitektur.html

7. P. Keromo, Faktor Kerosakan ke atas Monumen dan Tapak Tanah Bersejarah, Bengkel Konservasi Monumen dan Tapak Tanah Bersejarah, Melaka 2000, (2002).

8. A. G. Ahmad, Pemuliharaan Bangunan Warisan di Malaysia: Pengalaman dan Cabaran Masa Hadapan (2010)

9. A. G. Ahmad, Pemuliharaan Bangunan Warisan di Malaysia: Pengalaman dan Cabaran Masa Hadapan (2010)

10. N.W.Queen, L.Ayob, Early History of Penang (2012)

11. Jabatan Perancangan Bandar dan Desa, Rancangan Kawasan Khas George Town (2013)

12. S. N. Harun, Amalan Kerja Pemuliharaan Bangunan Bersejarah di Malaysia (2005) 